\title{
The Field of Geography
}

\section{Author(s): Clements R. Markham}

Source: The Geographical Journal, Vol. 11, No. 1 (Jan., 1898), pp. 1-15

Published by: geographicalj

Stable URL: http://www.jstor.org/stable/1774848

Accessed: 26-06-2016 15:48 UTC

\section{Your use of the JSTOR archive indicates your acceptance of the Terms \& Conditions of Use, available at}

http://about.jstor.org/terms

JSTOR is a not-for-profit service that helps scholars, researchers, and students discover, use, and build upon a wide range of content in a trusted digital archive. We use information technology and tools to increase productivity and facilitate new forms of scholarship. For more information about JSTOR, please contact support@jstor.org.

The Royal Geographical Society (with the Institute of British Geographers), Wiley are collaborating with JSTOR to digitize, preserve and extend access to The Geographical Journal 


\section{The \\ Geographical Journal. \\ No. 1. \\ JANUARY, 1898. \\ VoL. XI.}

\section{THE FIELD OF GEOGRAPHY.*}

By Sir CLEMENTS R. MARKHAM, K.C.B., F.R.S., President R.G.S.

IT was with great pleasure that $I$ received an invitation to address a meeting in this town, on the occasion of the founding of a Southampton Geographical Society. Similar institutions have met with success and have proved useful in Edinburgh, in Newcastle, in Manchester, and in Liverpool, and I think that there are special reasons why equal success should attend the laudable and patriotic efforts to found such a society in Southampton.

I have thought that it would be agreeable to such an audience as I might expect to have the honour of addressing here, consisting of people of culture all more or less interested in geographical subjects, if I were to include in what I have to say, a general glance at the work connected with our science in its numerous branches, an explanation of the duties undertaken by a society devoted to furthering the aims and objects of geography, and a review of the uses of local societies, both to the people within the sphere of their action and to the general welfare and advancement of geographical science.

Geography is a description of the Earth as it is, in relation to man, and a knowledge of the changes which have taken place on its surface during historical times. One aim of this science is to ascertain by what agencies and by what processes the Earth has acquired its existing forms and characteristics. Sir Richard Strachey has poetically compared geographical knowledge to a setting in which are gloriously held together the bright gems of science, to form an intellectual diadem for man. Geography is the mother of the sciences, whence all others have

* Opeling Address to the Southampton Geographical Society, November 17, 1897.

No. I.-JANUARY, 1898.] 
proceeded; and it is dependent on its offspring because it uses some of their facts, but looks at them from its own point of view. It deals with biology, but only from the point of view of geographical distribution and its causes. It deals with geology, but only so far as the past conditions explain and interpret the causes which have produced the present aspects of nature; while the geologist looks at the same facts from quite another standpoint-he studies the present that he may interpret the past. It deals with mathematics, but only so far as it is of practical use for accurate measurement, and for fixing the actual and relative positions of places on the Earth's surface. It is closely connected with meteorology and magnetism, because they deal with phenomena affecting the conditions of the Earth as an abode for man. Thus geography has been well defined by Dr. Mill, as the focus at which all the physical and historical sciences converge to throw light on the Earth as an organic whole. Mr. Mackinder has aptly summed up the work of geography with reference to the questions it answers. It first answers the question, "Where is it?" secondly, it answers the question, "Why is it there?" and, thirdly, it explains in what way its presence bears on the condition of man by affecting his environment.

It will thus be seen that geography is not a mere collection of names and of dry facts, but a body of knowledge of the deepest interest to every class in the community; while the adventures, the perils, and the heroism of the collectors of that knowledge form the brightest pages in our annals.

The first work of geographers is to answer the question, "Where is it?" To measure all parts of the earth and the sea, to ascertain the relative positions of all the places on the Earth's surface, and to delineate the varied features of that surface. This great work has been proceeding from the first dawn of civilization, and it will probably be centuries before it is completed. Explorers and geographers, surveyors and geodesists of each generation, work their allotted time, gradually increasing the stock of human knowledge by enabling other sciences and other branches of inquiry to make parallel advances; for they are all dependent on the accurate measurement and mapping of the Earth. Locality is one of the bases upon which all human knowledge must rest. Arts, sciences, administration, commerce, warlike operations, all depend upon correct geographical data. As those data become more extensive and more exact, so will every other human pursuit gain increasing light and truthfulness.

We are still very far indeed from an accurate geographical knowledge of even the most civilized countries, while by far the largest portion of the Earth's surface is inadequately surveyed, and a smaller part, though far from an inconsiderable part, is unsurveyed or entirely unknown. In the division of labour, the explorer forces his way into the unknown parts of the Earth; the surveyor follows, and furnishes us 
with topographical maps; and, finally, the geodesist produces, after rigorously exact surveys, those large-scale maps which meet the necessities of a highly developed civilization.

The first process, the actual discovery of unknown regions, usually attracts the greatest attention, because the heroic devotion and gallantry of travellers and navigators is an unending source of interest to old and young, and it has been so in all ages. All admirers of geographical achievement should ever bear in mind the story of the first known explorers. When they pass in review the deeds of the long roll of illustrious discoverers, down through the centuries, their starting-point should always be the tale told by Herodotus of the lads who, though young in years, are really the fathers of geographical discovery for its own sake.

On the shores of the Greater Syrtis, a deep gulf of the Mediterranean between Carthage and Cyrene, there dwelt, in remote ages, a Libyan tribe called Nasamonians. Five young men of their nation, enterprising youths of the highest rank, resolved to explore the vast deserts to the south of Libya. It would be a perilous enterprise even now ; but in those days it was an undertaking involving not only obvious difficulties, but also appalling unknown dangers. Much forethought was necessary in making preparations for the journey. The lads must have been prudent and thoughtful as well as courageous, for these qualities were necessary for success, and they succeeded. After crossing a region frequented by wild beasts, they entered upon the actual desert, and travelled across it for many days. At length they came to a grove of trees, where they were seized and led away prisoners by a number of black men of small stature. They were taken through extensive marshes, and at length came to a city whose inhabitants were black. A large river flowed by this city, and in it crocodiles were seen. The Nasamonians had crossed the Sahara, discovered the Hausaland of Sir George Goldie and the Niger Company, and had reached the river Niger. The point of the story is that the lads returned safely, and imparted the new geographical information to their people. Traders of the nation told it to Etearchus, king of the oasis of Ammon, who repeated it to some Greeks of Cyrene. These Greeks retailed it to Herodotus, and the Father of History has handed it down to us. It is our great landmark, this expedition of the young Nasamonians. For theirs is the first exploring enterprise in history made avowedly to penetrate beyond where any one had been before. And, moreover, they became the geographical instructors of their people. They performed the functions of a geographical society, as well as of an exploring expedition. They have had a long line of successors during the subsequent two thousand years. There have been Nasamonians-it is an appropriate name for them-in all parts of the world, by land and by sea. Their names and their deeds are known to us all, from Bruce and Mungo Park to Burton 
and Speke, and still more recent worthies. Nor is the race likely to become extinct. There are Nasamonians at work in every continent. Young Mr. Cavendish, a youth who reached the age of twenty-one last May, bas just returned from an important exploring journey in Africa. Sven Hedin, who will be with us in a few days, has climbed the urrascended mountain of Mustagata to 20,000 feet, and has, for the first time, traversed the desert of moving sand between Yarkand and Khotan, at the peril of his life. Persuade him to come down to Southampton and lecture to the members of your young society; you will then see the true type of a Nasamonian. It should be one of your objects to find out the boys in the schools of your neighbourhood who have the true Nasamonian instinct, and see that they are given a fair chance.

Stories of heroic devotion, true deeds of knight errantry, long and tried services, are recorded of our geodesists and rigorously accurate surveyors, as well as of our explorers and discoverers. It is a high honour, as well as a great advantage, to Southampton that the establishment of the Ordnance Survey has been in your midst for upwards of half a century. The names of Roy and Colby, of James and Clark, must be, they certainly ought to be, as household words amongst you. Their measured bases, their 350 trigonometrical points from the Shetlands to the Scilly islands, and from Valentia to Lowestoft, are miracles of accuracy. Think, too, of the amount of cultured skill, of patient industry, and of devotion to duty that they represent. The two principal base-lines on Salisbury plain and on the shores of Lough Foyle are 360 miles apart. To test the accuracy of the work, their lengths were computed through the series of triangles extending over the 360 miles, and compared with results by actual measurements. What do you suppose was the difference? Five inches! This is what I call a miracle of accuracy. Here are the compensation bars for measuring the bases, and hither, to this town of Southampton, have been brought the standards of all the civilized nations of the earth for comparison. England may well be proud of her geodesists. And not less honour is due to the British officers who have worked at the trigonometrical survey of India throughout this century. Their labours, too, have been conducted in a deadly climate, in the jungles and deserts of the low country, in pestiferous deltas, and on the snow-clad summits of Himalayan peaks. In the whole range of exploring narrative there is nothing more calculated to excite admiration, nothing more touching, than the devotion of Colonel Lambton, the first superintendent of the Great Trigonometrical Survey of India. 'The old man had been absorbed in his great work for half a lifetime. He was fast wasting away from exposure and hardship. But to the very last he brightened up to renewed animation and vigour when the great theodolite was brought before him. He died at his post in a wild part of Central India. This was nearly eighty years ago. But in our own time the equally heroic death of Colonel Basevi has been 
recorded. At a height of 17,000 feet above the sea, on a Himalayan peak, where the temperature was below zero, and protected only by a light tent, this martyr to science was engaged in the delicate operation of swinging the seconds pendulum. One morning, while gallantly striving to rise from a bed of suffering and continue his work, he fell back and died. These geodesists and their labours ought to be present in our minds when we use their maps. They must combine the knowledge of a Cambridge wrangler with the energy, resource, and presence of mind of an explorer or a backwoods-man; and they must add to all this the gallantry and devotion which inspire the leader of a forlorn hope. The danger of surveying service in the jungles and swamps of India, with the attendant anxiety and incessant work, is greater than the chances against one man on a battlefield; the percentage of deaths is larger, while the sort of courage that is called forth is of quite as high an order. When the stories of the Ordnance Survey in Great Britain, and of the Great Trigonometrical Survey of India are fitly told, they will form some of the very proudest pages in the history of our nation.

We owe even more to our navigators and marine surveyors, for they have discovered, surveyed, and mapped the coast-lines of the world, thereby creating the commerce and the material prosperity of Great Britain. It is often forgotten with what an expenditure of valuable lives this mighty result has been obtained, and with what devoted perseverance and resolution our sailors have worked during the last four centuries, actuated and inspired by the love of their fatherland.

We read with enthusiasm the narratives of the voyages of Drake and Cavendish, of Davis and Hudson, of Dampier and Cook, of Parry and Franklin. They stand out before us as beacons to light the way. But we must recollect that they are only the greatest achievements, and that hundreds of services, some almost and some quite as admirable, are forgotten or not so conspicuously recorded. In the survey of the coasts of Africa, the deadly climate has demanded a precious life for every 50 miles that has been laid down, while the first explorers of the Niger and the Congo have been mown down wholesale. In the arctic regions we meet with equally devoted zeal. Nothing has ever surpassed the heroism of Sir John Franklin and his companions. They struggled on, in the performance of duty, and their voyage has no equal. They discovered the North-West Passage, forging the last link of the chain with their lives. Nor are the deeds of the leading men who conducted the searches for Franklin less worthy of our admiration. Think of the labours of M'Clintock, who, without the aid of dogs, was away in a tent for one hundred and five days, and travelled over 1328 miles. Think of Mecham, who in seventy days, also without dogs, went over 1336 miles, at the rate of 20 miles a day. Think of Sherard Osborn, whose writings are as charming as his labours on the ice were admirable; of Vesey Hawilton, whom we still have among us; and of many others. 
More recent arctic work has proved that British explorers have not degenerated. The thrilling narratives of their exploits teem with deeds of devotion unequalled in all the deeds of knight-errantry. To select one out of many, I will mention what was done by my own young friends, Rawson and Egerton, in March, 1876. Their duty required them to set out over the ice, with a dog-sledge, and accompanied by the Danish dog-driver Petersen, when the thermometer was $-35^{\circ}$, that is, 67 degrees of frost, falling afterwards to $-50^{\circ}$, or 82 degrees of frost. Petersen was taken ill with cramp, and after that nothing would keep him warm. He was rapidly freezing, and if he had been alone, or with less devoted companions, he would soon have been dead. The two young officers burrowed a hole in the snow, covered it, and put Petersen. in, raising the temperature to $+7^{\circ}$, or only 25 degrees of frost. They then deprived themselves of all their own warm clothing, kept themselves alive by violent exercise, and took it in turn to warm Petersen at the expense of the heat of their own bodies. They succeeded, after long: persistence and great suffering to themselves, in restoring the circulation to Petersen's extremities. They thus brought the poor fellow on board alive. I have always, in my own mind, placed the conduct of Rawson and Egerton, on this occasion, among the finest things in the annals of arctic heroism. Wyatt Rawson, as is well known, fell mortally wounded. when guiding the Highland Brigade to the attack on the lines of Tel-el-Kebir. Egerton, now captain of the St. George, is one of the most distinguished officers in our navy.

Of this splendid courage, which knows no turning back from duty, no fear, no thought of self, our best discoverers and explorers are made. It is with such stuff that the greatness of our country has been built up; as well as by that moral courage which prompts men, in positions. of responsibility, to decide upon the right course, which is usually the boldest course. In this connection I will allude to Captain Philip Carteret, of the Swallow, because he was a resident in this town of Southampton. Carteret sailed with Captain Wallis in 1766 on a voyage round the world, his vessel being very small and merely a tender to the Dolphin, commanded by Wallis. After a harassing struggle through the long narrow Strait of Magellan, in the face of gales of wind and other dangers, they passed out into the Pacific. The two vessels were then separated during thick weather, and Captain Wallis had given no rendezvous. The Swallow was not fitted up for the long voyage without a consort. She had no forge, and all the articles of trade were on board the Dolphin. Carteret might, under these circumstances, when he found himself alone, have abandoned the voyage. But he was made of different stuff. He was not to be daunted. He conceived that his duty pointed to the westward, and he boldly went forward. In spite of sufferings from scurvy, scanty supplies, and a leaky ship, he circumnavigated the globe single-handed, and made an important discovery on the way. 
The reason I have selected Captain Carteret, among so many others, as a bright example of moral courage, is that he afterwards lived and died in this town of Southampton. He is one of your local geographical worthies.

My object in referring to these examples of heroic devotion among our travellers, geodesists, and navigators has been twofold. We ought to keep fresh in our minds the expenditure of energy, ability, and endurance, and the great loss of life that have been required to furnish us with reliable maps for our use and our instruction, to rejoice us with thrilling narratives of adventure which in themselves form an education, and to accumulate knowledge which has been of inestimable value, not only to this country, but to the whole civilized world. That expenditure, terrible though it has been and must continue to be, is fully justified, and more than justified, by the value of the results. Still it is very great. And when a devoted explorer falls, like Cook, or Franklin, or Livingstone, in the midst of his discoveries, his dying consolation is that his services will be appreciated and remembered by his country. It is for us, therefore, to keep the memory of such achievements ever green and fresh.

On the other hand, the stories of exploring labours, of gallant exploits in distant lands are the flowers which thickly strew the path of the geographical student, offering vivid pictures to his imagination, and giving an abiding and a living interest to all his studies.

The maps we have the privilege of using are the product of these gigantic labours. Their value to us cannot be over-estimated. They make us acquainted with all the world, they expound and explain the narratives which absorb us, in a way that no mere words can ever do. It is necessary to become familiar with them, but when that close acquaintance is obtained, they are documents which may be read, and which convey ideas and information like a book. The maps of the Ordnance Survey are now within the reach of all the people, and with them we can study the history of our country. We have the topographical ( 1 mile to an inch) maps, the county maps on a scale of a mile to 6 inches, and the parish plans on the much larger scale of a mile to 25 inches. Such maps-and there are similar publications in most of the countries of Europe-serve a thousand useful purposes. They are the basis of all inquiries conducted on scientific principles. Without them a geological survey is impossible; nor can botany, zoology, or ethnology be viewed in their broader aspects, unless considerations of locality, altitude, and latitude are kept in view. Not only as the basis. of scientific inquiry, but also for the comprehension of history and of operations of war, for administrative purposes, and for the illustration of statistics, the uses of accurate maps are almost infinite. M. Quetelet, in one of his well-known letters, declared that such graphic illustrations. often afforded immediate conviction of a point which the most subtle. 
mind would find it difficult to perceive without such aid. Maps both generalize and allow of abstraction. They enable inquirers at once to detect and offer to rectify errors which, if undetected, would affect results, and throw calculations into confusion. As an example of the use of maps for administrative purposes, the series constructed by $\mathrm{Mr}$. Prinsep in India is worthy of noticc. They showed the agricultural tribes of a special district arranged according to occupancy of land, fiscal divisions, physical features and zones of fertility, productive power as influenced by rain or irrigation, different kinds of soils, acres under different kind of produce, and lines of traffic. Another series displays irrigative canals, depth of wells, rainfall and zones of drought, and other features. Similar information is shown on the 'Cartes agricoles de France.' In no other way can economic and industrial facts be so lucidly and clearly, as well as so rapidly impressed on an inquirer's mind. Maps can also be made to illustrate history, and other fields of research in a thousand ways.

Narratives and maps are the chief ways in which we receive the results of labours in the field, and in due time they conduce to still mightier results by the opening of new regions for enterprise, and the dissemination of knowledge leading to discoveries of practical utility. It will at once occur to any one who contemplates the gradual accumulation of this mass of knowledge, that there would soon be need for some active agency to undertake its organization and distribution. In point of fact, this need has always existed, and we now come to the main part of our subject, the foundation of Geographical Societies.

The need has, of necessity, always existed even from the days of the illustrious travellers and explorers of the time of Queen Elizabeth, and we may take a hasty glance at the way in which this need has been more and more effectually supplied as the years rolled on. The duty was first done by the collection and publication of voyages and travels. We must go back to the reign of Queen Mary, and to this old town of Southampton on the day that Philip of Spain landed here, and rode on to Winchester in pelting rain, to be married to his elderly cousin. We follow Philip and Mary to their subsequent public entry into London. It was a gorgeous display, and among the admiring crowd there was a young undergraduate from Cambridge, named Richard Eden. He described himself as nearly lifted out of self-command by the excitement of the scene, and he resolved on the spot to set about some work which might fitly commemorate the event. He published his 'History of 'Travayle' in 1555, and strove in other ways to do the work now undertaken by a Geographical Society. His mantle fell on the shoulders of Hakluyt, who zealously continued the same work throughout the reign of Queen Elizabeth, publishing his great book, 'The Principal Navigations, Voyages, and Discoveries of Englishmen made by Sea and Land,' in 1598 to 1600. 
When the Royal Society was founded in 1665, for a century and a half it had to attend to all branches of science. Geography received some attention from it, but much less than any other science, and much less than its importance deserved. But this was more than made up for by the powerful influence of such personalities as Sir Joseph Banks and Major Rennell.

Sir Joseph Banks, the companion of Captain Cook in his first voyage, was a warm and active friend to geography during his long and useful life. In fact, he was the Geographical Society, to all intents and purposes, from 1778 until his death in 1820. He was an active member of the old African Association, formed for the exploration of that continent. He it was who obtained the order for forming the first settlement in Australia. He it was who, in conjunction with Sir John Barrow, raised the question of arctic research in 1818. We can read the narratives of very few explorers in those days who do not mention that they were helped either by representations to the Government, or by introductions, or by grants of money, or by advice from Sir Joseph Banks; while his most hospitable mansion in Soho Square was always open to geographers and explorers.

When Sir Joseph died in 1820, Major Rennell, the greatest among English geographers, took his place. He had been the SurveyorGeneral of India. $\mathrm{He}$ had constructed the map of Hindostan, which was the best for many years. He had prepared the map for Mungo Park's work, and had published the best maps of Africa. Travellers and explorers came to him with their rough work; projects were submitted to him for his opinion; reports were sent to him from all parts of the world. He presided over the labours of geographers, and formed a central rendezvous for help and advice. His forenoon receptions at No. 23, Suffolk Street, were frequented by all the geographers and explorers of the day. After the death of Sir Joseph Banks, the Geographical Society was Major Rennell. Hence it was that when Rennell died, at a good. old age, on March 29, 1830, the foundation of a Geographical Society became a necessity.

The Royal Geographical Society of London was founded in the year of Major Rennell's death. Its first meeting took place on May 24, 1830, and it has now been in full work for sixty-eight years. The African and Palestine Associations were merged in the new Society; and a very active branch society was formed in 1832 at Bombay, which came to an end in 1873, after the ill-advised abolition of the Indian Navy.

The work of the parent Geographical Society has been, first, to collect and disseminate geographical information by the publication of transactions, occasional volumes, and maps; by holding evening meetings where papers are read and discussed; by collecting a library, and making catalogues to facilitate the work of students in consulting 
it; by forming a large collection of atlases, maps, and photographs; and by throwing the map-room open to the public.

Secondly, to promote and encourage expeditions for discovery and for exploring little-known regions. This has been done by making representations to the Government-which have frequently been successful-by drawing up instructions and giving advice, by lending instruments, by making grants of money towards the equipment and subsequent expenses of expeditions, by training travellers, by publishing the volume called 'Hints to 'Travellers,' and by granting to successful explorers the Royal awards and other recognitions. The Society has also sent out expeditions at its own expense and under its direct control.

Thirdly, to further geographical education, first among travellers, but also in the educational establishments of the country. The first object was secured by a system of instruction at small cost to the pupils, by which intending travellers are taught to make celestial and other observations, to calculate their observations, to use and adjust instruments, to make outer surveys, and to construct maps. They are also taught photography, and can receive such lessons in geology and botany as will be useful to an explorer. The Society has also succeeded in getting a geographical readership permanently established in the University of Oxford, has assisted the cause of geographical education by large grants during more than a quarter of a century, and has now under consideration a considerable scheme proposed by Mr. Mackinder. The Royal Geographical Society strongly feels the want of properly trained teachers of geography in the secondary schools throughout the country. We wish to see the standard of teaching raised where it exists at all; we wish to see geography included in the curricula where it does not now find a place. We believe that then, and not till then, Government examination papers will be prepared in a very different way from what is now the case, with a view to testing knowledge instead of inflicting useless torture on the memory. We are seeking for the best means of raising up a body of trained teachers who will be able to make their influence felt for good; but it is a very difficult question, and progress will, I fear, be slow. At present Great Britain is far behind most of the continental nations as regards the teaching of geography.

In spite of the unfortunate position of geography as a subject in educational curricula, there is no doubt that the interest in geographical work has immensely increased among the general public during the last twenty years, and it has been found that there is ample room for local geographical societies to flourish and to do good work at several important centres. Manchester, I believe, set the example in 1884. I have myself had the pleasure of visiting the Manchester Society four years ago, and have witnessed its crowded meetings and its excellent 
methods of work. The example of Manchester was followed by Edinburgh in December, 1884, and the Scottish Society has had the great advantage of influential support from Mr. Bartholomew, the eminent cartographer of Edinburgh. The Geographical Society of Newcastleon-Tyne was founded in 1887, that of Liverpool in 1892, and both have received sufficient support, and have flourished. Evidently they are all filling obvious needs in their respective communities.

The aims and objects of local Geographical Societies would, I presume, speaking broadly, be much the same as those of the parent Society. They would endeavour to co-operate with existing local institutions, such as Chambers of Commerce, in the collection and diffusion of geographical information, probably paying a large share of attention to commercial geography. But there would, perhaps, be differences in this respect, with reference to the requirements of particular localities. They should all, however, devote attention to local topography and physical geography. I think it likely that the largest sphere of usefulness for local Geographical Societies will be found to be in the department of education, and here their influence ought really to be of national importance.

A society at Southampton, if well supported-and I sincerely trust that it will be so supported-appears to me to have a grand field of usefulness before it. The very position of Southampton seems to suggest the existence of such a society. The town must be full of cultured men with stores of reminiscences relating to voyages and travels. The great lines of steamers cannot have had their headquarters here for half a century without impressing the place with some marks of the two Indies. But the country itself is full of those features which are calculated to arouse interest in geographical evolution. You are at the head of a noble estuary penetrating far up into the eocene bed of Hampshire. The question, "Where is it?" is answered by the Ordnance Survey. But the further question, "Why is it there?" will be one of the problems which the Southampton Geographical Society will explain to its members. The eocene bed, on which your town rests, is surrounded and overlaid by chalk. What effect has this disposition of the land had upon the history of your neighbourhood? The Romans well understood the special value of particular sites, with reference to local advantages and to communications. Their reasons for placing their town of Clausentum on that peninsula formed by the river Itchen may well throw light on the geography of Southampton. When Cerdic and his Saxon army of colonizers landed here, they too, doubtless, had a reason for selecting this rather than any other port. This question will doubtless lead your members to consider the physical features of the Itchen valley, of the Gwent or Venta where Winchester now stands, and of the impenetrable fastnesses of Andredsweald. How did it happen that it was Jutes and not Saxons who found their way up the Hamble. 
and settled as the Meonwara at the foot of the chalk? In short, your members will desire to know the history of everything in their neighbourhood which has any bearing on its physical aspects. Your Hampshire cliffs of clay and sand will also claim your attention. You know that the Saxon cathedral of Selsea is gone, and that its site is now far out at sea. You will doubtless make investigations respecting the rate at which your cliffs are being washed away by the action of the waves, and whither the sediment is taken. I think that the researches of your society into the geographical evolution of your own county and into its history as explained by its geography, will be the most fascinating part of your labours.

But, of course, you will also have to go further afield. Southampton seems to be well suited for establishing relations with explorers and with foreign countries. Its proximity to London will render it more easy to secure capable geographers to give courses of lectures, and to induce eminent travellers to visit you. I think it may also be expected that the presence here of numerous officials connected with the great lines of steamers, and of consuls representing foreign countries, will be a great advantage to the Society. It is not ten years ago since Mr. H. Guillaume, the Consul-General of Peru at Southampton, published his work on the Amazonian Provinces as a field for European emigration. It is likely that there are other foreign representatives here who take a similar interest in geographical subjects, and who will support your movement. Referring to your long connection with the Royal Mail Company, it looks to me most probable that your interest in distant regions will often be turned in the direction of the Western Indies. In that case you will open to yourselves a very interesting field for research. Certainly, apart from the polar regions, the most extensive remaining unknown and undiscovered areas are in South America, a continent which yields to none in interest and in the value of its products, nor has it any rival in the charm, beauty, and variety of its scenery.

I cannot resist the impression, however, that the most solid and fruitful department of your work will be connected with education. Southampton has the great privilege of giving a home to the Ordnance Survey, which is in itself a notable source of instruction. It supplies lessons in exact surveving and in cartography, while furnishing you with those maps with which all young geographers ought to begin their studies-the maps of their own homes. There should be a popular history of the Ordnance Survey in the hands of all young geographers of Southampton. One was written some years ago by Captain Palmer, which only requires to be brought up to date.

The Society will also, I can scarcely doubt, be in close alliance with the Hartley College, and I sincerely trust that the college will establish a Professorship of Geography, with classes for commercial geography, and for nautical astronomy and navigation. It is now some years ago 
since the Royal Geographical Society resolved to offer a prize if classes were formed with a syllabus approved by the Society's Council, including-

Knowledge of the construction, adjustments, and use of instruments.

Determination of geographical positions from astronomical observations.

Rough surveying, bearings and distances, and determination of heights.

Construction of a rough map of a region, to scale.

Meteorological observations, reduction to averages, and drawing conclusions.

But, at that time, the Society's offer met with no response.

The professor might al-o train young geographers who, in their spare time, would become propagandists. The Manchester Geographical Society has long had a body of such youthful enthusiasts affiliated to it, who are called "Victorians." Well trained in the geographical subjects they undertake to propagate, they go forth to the towns and villages of Lancashire with lanterns and slides, and impart their own enthusiasm far and near. Through their means schoolmasters are indoctrinated with correct principles, and boys imbued with the geographical instinct, even in the most distant villages and the humblest positions, become known, and may have chances opened to them. 'I'he system of thus sending forth these geographical knights-errant has succeeded beyond expectation.

This is, I think, an example to follow. The young men of Southampton may equally be imbued with geographical enthusiasm, when they have been supplied with knowledge and trained as lecturers by the Hartley Professor. You need not give them the same name. Call them Nasamonians, after the geographical enthusiasts whose story has been handed down to us by Herodotus. A Nasamonian Club of such youths might be affiliated to your society. Mounting their bicycles, with lanterns and slides strapped on their backs, they would rush up the valleys of the Itchen, the Test, the Avon, and the Hamble, and penetrate to the remotest villages of the Meonwara. South Hampshire would become a geographically enlightened region, with your society as its centre. Ordnance Survey Maps of the parishes would be hung in all the village school-rooms, and masters would co-operate with the Society, and would teach fiom them on correct principles. Boys with geographical instincts and the desire to take trouble and to do well, would thus find opportunities, instead of having their hopes and aspirations crushed out of them. As members of the Nasamonian Club, they will be able to obtain encouragement, guidance, and information. Think by what mere chances our most illustrious geographers have been saved to us. Doubtless as many have been lost to us from never having had a chance.

Take the example of James Rennell, a friendless boy in the village of Chudleigh, in Devonshire. In 1756 the clergyman of the parish got. 
him an appointment in a man-of-war. That was his chance. He devoted himself to geography, to making surveys and drawing charts. The rest of his story is like a fairy tale. In those days there was no promotion in peace time but through interest. Young Rennell had none. So 'at the end of the seven years' war he got his discharge at Madras. He received command of a small vessel belonging to the East India Company. She was lost in a hurricane. A merchant kindly made him master of a schooner going to Calcutta. When he arrived, the Governor of Bengal was looking out for some one to make a survey of the Company's dominions. His Excellency's private secretary had been an old messmate of Rennell's. He told the Governor that the master of a schooner in the Hugli was an admirable surveyor. The discharged midshipman, at the age of 22, was made Surveyor-General of India at a very large salary, received a commission in the Bengal Engineers, and in course of time became England's greatest geographer. The moral of which is-give your boys a chance.

Remember, too, the case of James Cook, the son of a poor farm labourer with a large family, and apprenticed on board a collier brig. $\mathrm{He}$ had the true geographical instinct. But he also had perseverance and the determination to do well-" Talant de bien faire," as it is expressed in the motto of Prince Henry the Navigator. Cook must have worked very hard in the nine years during which we know nothing of him. His chance came when he volunteered for a man-of-war as an able seaman to avoid the press-gang, and when Sir Hugh Palliser noticed his intelligence and zeal, he was made an officer. After ten years the value of his surveying services in North America had become so conspicuous that the Secretary of the Admiralty recommended him to command an expedition of discovery. The poor friendless boy, apprentice in a collier brig, became the most illustrious navigator that this nation has ever produced.

There are Rennells and Cooks in Hampshire villages now, waiting for the Southampton Geographical Society to found a Nasamonian Club. Not many years ago a ragged little boy came to a night school not a hundred miles from the Hartley Hall, and asked to be admitted. $\mathrm{He}$ was told that he could come in if he paid a shilling. He was going away with tears in his eyes, when the teacher, who was a kind-hearted man, was touched by his sorrowful face. He said he would let the boy come in without paying if he proved worthy. In a short time the boy was miles ahead of everybody else. He is now an officer of high rank in an important and responsible position. This shows that a teacher will do well to think twice, even three times, before he turns away a penniless little boy who wants to learn.

I have had no thought beyond throwing out hints for what they may be worth, in thus dwelling upon the work which might be undertaken by your society. But geography is many-sided, and equally good and 
useful work may be done on other lines. Whatever the plan may be, I sincerely trust that the Society will flourish and become a centre of humanizing influences, collecting information, spreading geographical knowledge, promoting education, and guiding and encouraging youthful talent.

In conclusion, I may mention that the Royal Geographical Society will have pleasure in welcoming the members of the Southampton Society when they visit London. They will have the use of the Society's rooms, the privilege of consulting the library and map-room; they will be given tickets on application to any of the Society's meetings; and they will be allowed to purchase the Society's publications at the Fellows' prices, which is less than those paid by the general public. It only remains for me to express my warmest wishes for the success of the Southampton Geographical Society.

\section{TWO RECENT JOURNEYS IN NORTHERN SOMALILAND.*}

\section{By F. B. Parkinson, Assoc. R.S.M., and Lieut. Brander-Dunbar, 2ND Cameron Highlanders.}

Ir was in October, 1894, returning from Australia with my friend Mr. Brander-Dunbar, that, on entering the Gulf of Aden, our conversation naturally turned to Somaliland. We had both of us read scraps about it sufficient to whet our appetites. We had heard of the high and healthy platean of the interior, of luxuriant mimosa forests, of lions, of elephants, of semi-wild natives mounted on semi-wild horses, and of suchlike things, that made us vow that if ever opportunity occurred we also would visit Somaliland, and see if there was anything left for us to discover.

Such opportunity came in the autumn of last year, 1896 ; but before commencing the record of what we saw and did, I take the opportunity of thanking the Society for the material assistance given us in the form of a loan of instruments, which enabled an accurate survey of the route, and also of the adjacent country, to be made. My best thanks are also due to several gentlemen for valuable advice and information, namely, Dr. Scott Keltie, Secretary of the Society; Mr. Coles, the Society's Instructor; Mr. Ravenstein; Prof. Howes, of the Royal College of Science; Dr. Woodward and Dr. Gregory, of the British Museum; and the Hon. Major Talbot, of the Department of Military Intelligence at the War Office. Also our trip would not have been so easy of 